\title{
PELAKSANAAN PERATURAN WALIKOTA DENPASAR NOMOR 36 TAHUN 2018 TENTANG PENGURANGAN PENGGUNAAN KANTONG PLASTIK
}

\author{
Ni Luh Yuni Setyawati, I Ketut Kasta Arya Wijaya, Luh Putu Suryani \\ Fakultas Hukum, Universitas Warmadewa, Denpasar-Bali, Indonesia \\ yunisetyawati825@gmail.com, kastaaryawijaya@gmail.com, putusuryani099@gmail.com
}

\begin{abstract}
Abstrak
Sampah plastik menjadi salah satu penyebab timbulnya permasalahan lingkungan. Oleh karena itu, Pemerintah Kota Denpasar menerbitkan Peraturan Walikota Tentang Pengurangan Penggunaan Kantong Plastik. Tujuan penelitian ini guna untuk mengungkap pelaksanaan Peraturan Walikota Denpasar Nomor 36 Tahun 2018 tentang Pengurangan Penggunaan Kantong Plastik dan faktor-faktor penghambat dalam pelaksanaan Peraturan Walikota Nomor 36 Tahun 2018. Tipe penelitian yang digunakan adalah penelitian hukum empiris dengan pendekatan perundang-undangan. Teknik pengumpulan bahan hukum dilakukan dengan observasi, wawancara dan metode dokumentasi. Sumber data yang digunakan yaitu sumber data primer dan sekunder. Setelah data terkumpul, maka data dianalisis dengan teknik analisis deskriptif. Hasil pembahasan mengungkapkan bahwa peraturan Walikota dibentuk bertujuan untuk mengendalikan kerusakan lingkungan maupun menjamin keberlangsungan makhluk hidup. Pelaksanaan peraturan ini belum berjalan efektif karena masih banyak terdapat pelaku usaha maupun masyarakat yang menggunakan kantong plastik tanpa menggantinya dengan kantong alternatif. Faktor penghambat dalam pelaksanaan Peraturan Walikota Denpasar No. 36 Tahun 2018, yaitu kurangnya kesadaran masyarakat akan bahaya yang ditimbulkan dari penggunaan kantong plastik sekali pakai, adanya pandemi covid-19 yang menghambat program pemerintah dalam mensosialisasikan peraturan ini secara langsung. Upaya yang dapat dilakukan pemerintah dalam mensosialisasikan pengurangan penggunaan plastik hanya dapat dilakukan secara virtual melalui media massa berupa radio dan televisi.
\end{abstract}

Kata Kunci: Masyarakat, Plastik, Pelaksanaan Peraturan Walikota

\begin{abstract}
Plastic waste is one of the causes of environmental problems. Therefore, the Denpasar City Government issued a Mayor Regulation on Reducing the Use of Plastic Bags. The purposes of this study are to reveal the implementation of the Denpasar Mayor Regulation Number 36 of 2018 concerning Reducing the Use of Plastic Bags and the inhibiting factors in the implementation of the Mayor's Regulation Number 36 of 2018. The type of research used is empirical legal research with a statutory approach. The technique of collecting legal materials is done by observation, interviews and documentation methods. Sources of data used are primary and secondary data sources. After the data was collected, the data were analyzed using descriptive analysis techniques. The results of the discussion revealed that the Mayor's regulation was formed with the aim of controlling environmental damage and ensuring the sustainability of living things. The implementation of this regulation has not been effective because there are still many business actors and people who use plastic bags without replacing them with alternative bags. Inhibiting factors in the implementation of Denpasar Mayor Regulation No. 36 of 2018, namely the lack of public awareness of the dangers posed by the use of single-use plastic bags, the existence of the covid-19 pandemic which hinders government programs in directly socializing this regulation. Efforts that can be made by the government in socializing the reduction of plastic use can only be done virtually through mass media in the form of radio and television.
\end{abstract}

Keywords: Implementation of Mayor Regulations, Community, Plastic

\section{PENDAHULUAN}

Perkembangan serta kemajuan di tengah masyarakat menyebabkan juga terjadinya peningkatan yaitu dari segi produksi. Dengan adanya kebutuhan masyarakat yang semakin berkembang dalam hal ini laju volume sampah semakin meningkat juga dikarenakan pola konsumsi semakin meningkat yang tentunya berbanding terbalik dengan pertumbuhan penduduk. Sampah merupakan hasil sisa dari suatu kegiatan yang dilakukan oleh manusia adapun yang dimaksud dengan sampah adalah merupakan limbah sisa hasil dari produksi industri ataupun hasil dari limbah rumahan. Sampah memiliki berbagai ragam jenisnya, salah satunya adalah sampah plastik (Helmi, 2012). 
Plastik adalah jenis sampah berupa anorganik, plastik sangat mudah untuk didapatkan. Dikarenakan plastik merupakan bahan yang mudah untuk dipakai dan pemakaiannya bisa digunakan untuk berbagai jenis kegiatan seperti menaruh makanan, membawa barang belanjaan dan berbagai jenis kegiatan. Akan tetapi dibalik kemanfaatannya tersebut, juga terdapat sisi yang tidak baik dari segi penggunaan plastik tersebut. Menurut penelitian menunjukan bahwa plastik menyebabkan berbagai macam jenis penyakit seperti memicu terjadinya kanker. Serta selain itu salah satunya adalah susahnya sampah plastik untuk diuraikan sehingga sampah plastik bisa dikategorikan bisa merusak lingkungan dan kesehatan. Plastik diolah berbagai macam jenis seperti menjadi kantong plastik. Masyarakat sangat menggemari penggunaan kantong plastik dikarenakan mudahnya kegunaan yang bisa dilakukan menggunakan kantong plastik, Banyaknya peminat di masyarakat menyebabkan meningkatnya jumlah produksi plastik. Tentunya hal ini akan berdampak pada tingginya limbah yang dihasilkan oleh plastik, mengingat akan merusak lingkungan dalam hal ini perlu disadari bahwa plastik sangat susah untuk diuraikan sehingga akan berdampak merusak lingkungan sekitar akibat limbah yang dihasilkan. Persoalan seperti ini harus sangat diperhatikan dengan serius (Akib, 2014).

Pada dasarnya manusia sudah sangat bergantung pada kegunaan kantong plastik ini, kemudahan yang mereka rasakan adalah kantong plastik sangat mudah untuk didapatkan dan mudah digunakan dalam berbagai kegiatan yang dilakukan. Meniadakan penggunaan kantong plastik ini tidak sepenuhnya bisa berhasil dilakukan akan tetapi jika masyarakat mampu untuk bekerjasama untuk memahami bahaya penggunaan plastik secara berlebihan akan mengakibatkan kerusakan pada kesehatan dan lingkungan. Dalam hal ini sebenarnya hal yang bisa dilakukan oleh masyarakat tentunya bisa diberikan regulasi dari pemerintah itu sendiri untuk mengurangi penggunaan sampah plastik yang ada. Tumbuhnya limbah plastik terjadinya akibat kian pesatnya juga perkembangan penduduk. Seperti jumlah penduduk yang berada di Denpasar yaitu berjumlah 647.954 sehingga jumlah limbah yang dihasilkan tentunya akan mengalami jumlah yang hampir sama dengan jumlah penduduk tersebut.

Pada data yang ada pada tahun 2018 memperlihatkan bahwa kota Denpasar menjadi salah satu penyumbang sampah terbesar di Provinsi Bali. Denpasar yang merupakan kota yang memiliki penduduk yang padat tentunya memiliki jumlah dan produksi limbah pastinya bertambah meningkat. Permasalahan sampah menjadikan masalah jangka panjang yang dimana hal ini terjadi jatuh setiap tahunnya. Dikarenakan naiknya jumlah sampah yang terjadi melebihi jumlah dari penduduk yang ada di Kota Denpasar. Tentu hal ini berdasarkan data yang diperoleh seperti pada tahun 2016 terdapat sampah 850 per ton tiap harinya dan terjadi begitu peningkatan pada tahun 2017 yang dimana mendapat sampah sampai 900 ton seharinya. Pada saat pemerintahan yang terdahulu sudah melakukan beberapa upaya untuk melakukan pencegahan agar tidak semakin banyaknya masyarakat yang menggunakan kantong plastik. Hal ini berjalan guna untuk menghindari pencemaran lingkungan yang tiap harinya tercemar akibat dari limbah kantong plastik tiap harinya. Tentunya yang dimana limbah plastik sangat berdampak pada kesehatan dan lingkungan sekitar kita.

Maka dari itu sempat terjadi beberapa peraturan yaitu berupa tiap kantong plastik harus dilakukan dengan berbayar guna mencegah penggunaan secara berlebih yang terjadi di tengah masyarakat tersebut. Akan tetapi kebijakan yang terjadi tersebut sama sekali tidak efektif dan dijalankan dengan baik di masyarakat. Setelah selang beberapa lama peraturan tersebut dijalankan dan tidak membuahkan hasil yang diinginkan. Maka terciptalah aturan baru yang lebih tegas guna mencegah semakin banyaknya penggunaan masyarakat yang memakai kantong plastik. Yaitu melakukan pengurangan penggunaan plastik dengan cara mengganti kantong plastik menjadi kantong alternatif lainnya yang tentunya ramah lingkungan. Lebih lanjut, gagasan untuk memberikan jaminan keindahan dan kenyamanan untuk masyarakat dan wisatawan yang berkunjung menjadi turis ke Bali dituangkan dalam bentuk regulasi juga diatur dalam Peraturan Derah Bali Nomor 97 Tahun 2018 tentang Pengurangan Penggunaan Kantong Plastik atau Pembatasan Timbulan Sampah Plastik Sekali Pakai (Adhi et al., 2021); (Kubontubuh, 2019).

Penelitian terdahulu yang relevan dengan penelitian ini mengungkapkan bahwa implementasi hukum terhadap Peraturan Walikota Nomor 36 Tahun 2018 belum dapat dilakukan dengan baik yang dimana pada pelaku usaha di pasar tradisional tidak semua pelaku usaha dapat melakukan kegiatan jual beli tersebut, hal ini dikarenakan tidak semua barang yang diperjual belikan dapat dikemas menggunakan kantong alternatif (Abhiseka \& Suharta, 2019). Sedangkan menurut Karuniati \& 
Muhammad (2021) implementasi kebijakan yang diterapkan oleh pemerintah dengan hasil kerjasama dari berbagai pihak dapat terlaksana dengan baik di Kota Denpasar. Walaupun masih terdapat beberapa kendala yaitu kurangnya pengawasan dari pemerintah terutama di pasar-pasar tradisional yang menyebabkan kurangnya kesadaran masyarakat untuk menaati aturan belum adanya industri yang bisa mendaur ulang kantong plastik. Adapun penelitian dari Blolo (2021) pelaksanaan kebijakan berjalan dengan lancar dan sesuai ekspektasi dengan melaksanakan pembagian tas ramah lingkungan menemukan bahwa pelaksana. Telah terjadi komunikasi dan sosialisasi kebijakan regulasi. Komunikasi internal pelaksana sangat baik dalam mensosialisasikan kebijakan. Kelompok sasaran mendukung aturan tersebut. Maka berdasarkan fenomena tersebut dilakukanlah penelitian yang bertujuan untuk mengungkap pelaksanaan Peraturan Walikota Denpasar Nomor 36 Tahun 2018 tentang Pengurangan Penggunaan Kantong Plastik serta faktor-faktor penghambat dalam pelaksanaan Peraturan Walikota Nomor 36 Tahun 2018.

\section{METODE PENELITIAN}

Sesuai pada permasalahan yang muncul maka jenis tipe penelitian yang dilakukan pada penulisan ini adalah menggunakan penelitian hukum empiris yang dimana bahwa hukum digambarkan dengan mengamati kehidupan yang nyata dan penelitian empiris merupakan data yang didapat langsung pada masyarakat serta mendapat suatu permasalahan yang terjadi saat di lapangan. sumber data hukum yang digunakan yaitu sumber data primer merupakan sumber data yang diperoleh secara langsung dari narasumber atau responden baik melalui wawancara, observasi untuk mendapatkan sebuah informasi di lapangan serta umber data sekunder adalah data yang diperoleh dari studi kepustakaan dapat berupa peraturan perundang-undangan, jurnal, dokumen-dokumen dan buku-buku yang berkaitan dengan masalah yang terjadi sebagai landasan hukum. Lokasi pengumpulan data dalam penelitian ini yaitu dilaksanakan di Kota Denpasar. Dimana akan meneliti pada Dinas Lingkungan Hidup Kota Denpasar yang beralamat di Jalan Majapahit No.6, Dauh Puri Kaja Kecamatan Denpasar Utara dan pelaku usaha yang berada di Kota Denpasar. Dalam hal ini peneliti akan melakukan observasi, wawancara dan metode dokumentasi dengan mendapat data yang bersangkutan dengan atau variable sebagaimana berbentuk transkip, buku, majalah, agenda dan hal- hal lainnya yang bersangkutan. Pada saat data primer yang mencakup wawancara dan observasi telah terkumpul, begitu pula data sekunder yang meliputi perundang- undangan. Dapat dilanjutkan pengolahan dan analisis data. Metode analisis data yang digunakan dalam penelitian ini adalah metode analisis kualitatif dengan teknik analisis deskriptif.

\section{HASIL DAN PEMBAHASAN}

\section{Pelaksanaan Peraturan Walikota Denpasar Nomor 36 Tahun 2018 Tentang Pengurangan} Penggunaan Kantong Plastik

Sampah pada dasarnya merupakan hasil limbah dari suatu hasil produksi baik itu berasal dari pabrik maupun berasal dari limbah rumah tangga selain itu sampah merupakan hasil dari kegiatan yang dilakukan oleh manusia. Sampah adalah merupakan hal permasalahan yang sangat krusial dikarenakan dampak yang diberikan begitu sangat besar pada manusia saat ini (Asshidiqie, 2005). Sampah yang diakibatkan oleh manusia itu sendiri, semakin lama menjadi semakin tidak terkendali, hal ini tentunya terjadi akibat dari produksi yang dihasilkan semakin banyak. Persoalan ini sudah sangat jelas menjadikan tempat tinggal menjadi tidak ramah akan kesehatan dan lingkungan.

Permasalahan sampah memang tidak akan bisa selesai dikarenakan tingkat penduduk yang padat menyebabkan tingkat produksi semakin naik juga. Seperti halnya kantong plastik yang dimana setiap saatnya sangat diperlukan dalam berbagai proses kegiatan oleh masyarakat. Seperti berbelanja menggunakan kantong plastik, yang dalam hal ini sudah pasti dikatakan bahwa kantong plastik begitu dibutuhkan oleh masyarakat dalam berbagai kegiatan. Kegiatan yang dilakukan oleh masyarakat dalam memakai kantong plastik, tentunya harus sangat diperhatikan mengingat bahwa plastik merupakan jenis anorganik yang begitu sangat berbahaya dikarenakan bahan kimia yang digunakan tidak baik itu kesehatan maupun lingkungan sekitar kita. Sampah plastik merupakan bahan yang paling sangat susah diuraikan baik itu secara alami, untuk terjadinya penguraian tersebut perlu terjadi beratus tahun lamanya. Penjelasan dari kantong plastik ini terdapat juga terdapat dalam Pasal 1 angka 5 Peraturan Walikota Nomor 36 Tahun 2018 menjelaskan bahwa kantong plastik adalah terbuat dari plastik atau lateks. 
Pemakaian plastik pada kehidupan manusia sudah sangat menjadi ketergantungan, selain memudahkan untuk melakukan segala kegiatan plastik juga tahan akan air dan panas. Sehingga makanan ataupun barang yang ditaruh dalam kantong plastik akan tidak mudah rusak (Manik, 2009). Akan tetapi manusia lupa akan bahaya dari plastik, berikut penjelasan mengenai tentang dampak dari plastik akan menimbulkan permasalahan lingkungan seperti. Tercemarnya air dan tanah, racun-racun yang dihasilkan oleh plastik akan diserap oleh tanah sehingga menyebabkan terjadi keracunan bagi makhluk hidup yang berada di bawah tanah tersebut, jika sampai sampah plastik berada di laut akan menyebabkan paus, penyu serta hewan lainnya menganggap sampah plastik merupakan makanan mereka. Maka dari itu perlu adanya aturan yang tegas dalam mengatur permasalahan tersebut. Peraturan merupakan hal ketentuan yang bersifat mengikat serta mengatur yang tentunya harus ditaati guna terciptanya kestabilan dan ketentraman. Dan apabila terjadi penyimpangan akan dikenakan sanksi atau hukuman yang berlaku yang sudah disepakati.

Dalam hal ini kewenangan dari pemerintah Kota Denpasar pada program mengurangi kantong plastik sudah diatur pada Peraturan Walikota Nomor 36 Tahun 2018 tentang Pengurangan Penggunaan Kantong Plastik. Tentunya kewenangan ini tercipta agar masyarakat memiliki kesadaran yang lebih tinggi lagi guna menciptakan lingkungan yang baik. Keikutsertaan dari berbagai elemen begitu sangat diperlukan guna bersama saling menjaga lingkungan. Pemerintah Kota Denpasar sudah mengeluarkan peraturan sebagaimana yang disebutkan pada pasal 5 Peraturan Walikota Denpasar No. 36 Tahun 2018 bahwa setiap pelaku usaha harus menggunakan kantong alternatif adapun hal ini harus dilaksanakan pada pusat perbelanjaan serta toko modern lainnya. Yang dimaksud menggunakan kantong alternatif adalah salah satunya ialah paper bag yang tentunya sangat ramah lingkungan dan aman bagi kehidupan manusia serta tidak mencemari lingkungan.

Dengan adanya regulasi menyangkut pengurangan pemakaian kantong plastik supermarket merasa sangat diuntungkan, seperti pengakuan dari salah satu pemilik supermarket yang menjelaskan bahwa karena adanya peraturan tersebut saya merasa diuntungkan karena tidak perlu mengeluarkan biaya tambahan untuk membeli kantong plastik. (Wawancara dengan Kadek Krisna, pada tanggal 16 Maret 2021). Tetapi pada pasar tradisional ditemukan beberapa kendala yang terjadi pada pelaku usaha yang dimana dagangannya tidak semua bisa menggunakan paper bag tersebut dikarenakan dagangannya berupa daging yang biasanya menggunakan plastik guna menahan daging yang lembab tersebut tidak menjadi basah saat membacanya, maka tidak bisa mempergunakan kantong alternatif pada umumnya. Adapun hasil data persentase yang memperlihatkan bahwa toko modern lebih banyak memberi pengurangan sampah plastik jika kita membandingkan dengan pasar tradisional maupun toko lainnya. Hal ini juga dikarenakan pasar tradisional beradaptasi pada perwali mengenai pengurangan kantong plastik tersebut.

\section{Faktor-Faktor Penghambat Dalam Pelaksanaan Peraturan Walikota Nomor 36 Tahun 2018}

Program yang dilaksanakan oleh pemerintah Kota Denpasar dalam mengurangi kantong plastik masih memiliki kendala serta hambatan, yang menjadi persoalan adalah dikarenakan tidak secara menyeluruh aturan ini diterapkan pada pusat perbelanjaan yang ada. Dalam hambatan ini yang menjadi dasar paling utama yaitu akibat dari kantong alternatif yang tidak sama kualitasnya dengan kantong plastik dan tidak praktis dikarenakan lebih tebal. Menyangkut mengenai adanya penerapan dari Perwali No.36 Tahun 2018 tentang Pengurangan Penggunaan Kantong Plastik, pembeli menjadi bingung yang mana menghadapi permasalahan apabila pembeli ketika berbelanja tetapi tidak diberi kantong pembungkus belanja, tetapi pembeli diberi pilihan seperti setelah berbelanja tidak menggunakan kantong untuk membawanya atau membeli kantong belanja alternatif yang sudah ada pada toko tersebut jika ingin membeli maka kasir akan memberitahu jumlah harga yang dikeluarkan untuk membeli kantong alternatif tersebut dan bisa juga pembeli membawa dari rumah.

Dengan kebijakan perwali seperti itu diharapkan kepada pembeli maupun masyarakat untuk lebih peduli terhadap lingkungan akibat dari sampah plastik yang dihasilkan tersebut. Semakin bertambahnya kesadaran masyarakat maka semakin tinggi juga akan pengurangan sampah plastik yang terjadi (Arifin, 2017). Walaupun sudah dinilai cukup baik akan tetapi masih saja ada penghambat. Hal ini terjadi dikarenakan mungkin membuat masalah kepada pelaku usaha. Seperti salah satu pengakuan penjual snack grosiran di Pasar Agung Peninjoan yang menyebutkan bahwa kendalanya banyak pembeli yang mengeluh serta komplain jika tidak diberikan kantong plastik terkadang konsumen tidak jadi membeli, biasanya kebanyakan orang tua seperti ibu-ibu, tetapi ada 
juga yang terima dan ada juga yang tidak (Wawancara dengan Ni Made Lestarini, tanggal 15 Maret 2021). Hal ini terjadi tentunya karena masyarakat sudah terbiasa menggunakan kantong plastik, yang dimana bahan serta penggunaanya lebih praktis dan ekonomis karena diberikan langsung oleh para pedagang ketika pembeli berbelanja di Toko mereka. Maka masyarakat sangat sulit untuk melakukan peralihan dari kebiasaan yang sudah lama dilakukan ini.

Masyarakat tidak ingin susah dalam hal berbelanja, apalagi sampai membawa kantong yang tidak mudah dibawanya. Maka masyarakat memang harus beradaptasi menggunakan kantong alternatif ini. Jika masyarakat berhasil bekerjasama dengan baik, maka kebijakan yang dibuat akan sejalan agar terciptanya lingkungan yang bersih dan sehat. Atas dasar itu yang menjadikan faktor paling utama dalam penghambatan terlaksananya Perwali tersebut dikarenakan masyarakat itu sendiri masih belum terbiasa mengganti kebiasaan terdahulu yang selalu menggunakan kantong plastik sebagai wadah berbelanja. Adapun faktor internal yang menyebabkan terjadinya kendala, yaitu covid-19. Virus yang begitu sangat cepat menyebar keseluruh dunia tidak terkecuali Kota Denpasar. Adanya pandemi ini menyebabkan terhambatnya aturan ini berjalan. Seperti tidak bisanya mensosialisasikan tentang bagaimana penggunaan kantong alternatif ini. Dengan adanya sosialisasi sebenarnya hal ini akan mempengaruhi masyarakat untuk akan lebih sadarnya menggunakan bahan alternatif lain selain plastik. Ketika masyarakat sudah bisa untuk memahami, maka tidak akan ada perdebatan serta penentangan baik itu dari penjual maupun pembeli. Sosialisasi begitu sangat diperlukan agar terwujudnya suatu pemahaman yang jelas di Masyarakat. Tetapi walaupun ditengah pandemi ini sosialisasi tetap berjalan sebagaimana mestinya yang memberikan informasi tentang penggunaan kantong alternatif. Yang tentunya sosialisasi ini dilakukan dengan cara virtual seperti melalui tv serta radio dan yang paling penting melalui sosial media, yang dimana sosial media paling sering digunakan oleh masyarakat saat ini.

Sosialisasi dilakukan melalui virtual ini tentu memiliki kendala, seperti masih adanya masyarakat yang tidak bisa menggunakan alat komunikasi canggih ini guna mendapatkan informasi, selain itu hal yang dilakukan secara virtual ini menyebabkan tidak bersemangatnya para penerima informasi, dikarenakan penerima hanya mendengarkan teori saja tanpa praktek yang dilakukan tentunya sangat berbeda ketika memberikan pemahaman dengan cara tatap muka. Yang dimana perlu disadari bahwa dampak dari penggunaan kantong plastik begitu sangat akan berdampak besar bagi lingkungan. Maka dari itu untuk mengatasi persoalan yang terjadi, Pemerintah memiliki solusi tersendiri yaitu dengan bekerja sama dengan Dinas Lingkungan Hidup dan Kebersihan Kota Denpasar guna terciptanya pelaksanaan dari Perwali tersebut. Berdasarkan penjelasan Pak Adi Wiguna bahwa kegiatan sosialisasi secara langsung mungkin belum efektif dan sulit untuk dilakukan apabila harus satu persatu, maka kita juga menyampaikan serta mengajak komponen masyarakat seperti melalui kepala desa, camat, tokoh-tokoh masyarakat (Wawancara dengan I Ketut Adi Wiguna selaku Kepala Bidang Pengelolaan Sampah dan Limbah B3, Dinas Lingkungan Hidup dan Kebersihan Kota Denpasar, pada tanggal 9 Maret 2021). Dinas lingkungan Hidup dan Kebersihan Kota Denpasar memberikan penjelasan bahwasannya sosialisasi ini memang sangat sulit untuk dilakukan sosialisasi satu persatu kepada masyarakat dikarenakan masyarakat yang sangat banyak dengan petugas yang terbatas menyebabkan hal tersebut menjadi kendala memberikan informasi maka dari itu perlu menggandeng beberapa komponen di wilayah masing-masing untuk menyebarkan informasi tersebut.

\section{SIMPULAN DAN SARAN}

\section{Simpulan}

Pelaksanaan Peraturan Walikota Denpasar Nomor 36 Tahun 2018 Tentang Pengurangan Penggunaan Kantong Plastik yang dilaksanakan oleh pemerintah yaitu dengan cara memberikan sosialisasi serta himbauan guna pelaku usaha menyediakan alternatif dan tentunya tidak memberikan kantong plastik kepada pelanggan. Pada hal ini sudah berjalan dengan lancardan baik akan tetapi belum sepenuhnya berjalan $100 \%$ penuh dengan yang diharapkan. Penerapan yang terjadi pada toko modern sudah berhasil mengurangi sebanyak 99,60\% dari 95 pelaku usaha, pada pasar tradisional sebanyak 54,26\% sedangkan pada usaha yang lainnya sebanyak $86,27 \%$. Menyangkut apabila terjadi pelanggaran maka akan dikenakan sanksi berupa administrasi, akan tetapi sebagai tahap awal pelanggar akan diberikan pemahaman. Apabila masih berulah maka pelaku usaha akan dipertimbangkan untuk memperpanjang izin usahanya tersebut. Adapun faktor-faktor penghambat dalam pelaksanaan Peraturan Walikota 
Denpasar Nomor 36 Tahun 2018 Tentang Pengurangan Penggunaan Kantong Plastik memiliki dua faktor yaitu eksternal serta internal. Kurangnya pemahaman pada masyarakat yang menyebabkan terjadinya hambatan dalam menjalankan regulasi tersebut, hal ini termasuk dari faktor eksternal. Sedangkan faktor internalnya yaitu dikarenakan pandemi covid-19 menyebabkan terjadinya berbagai macam permasalahan salah satunya yaitu cara memberikan informasi yang jelas tidak bisa tersampaikan dikarenakan tidak bisa tatap muka, akan tetapi pemerintah sudah melakukannya secara virtual.

\section{Saran}

Peran pemerintah diharapkan cepat dalam mensosialisasikan informasi mengenai kantong plastik guna terwujudnya lingkungan yang baik dan sehat. Pemerintah juga seharusnya melakukan pengawasan secara langsung agar dapat langsung menindak pelanggar yang masih tidak menggunakan kantong alternatif. Bagi pelaku usaha diharapkan untuk menyediakan kantong alternatif di toko mereka berjualan, guna dapat mengurangi pemakain kantong plastik yang digunakan oleh pembeli, serta masyarakat diharapkan untuk sadar serta memahami informasi yang beredar guna pemakaian kantong plastik sangat berbahaya bagi lingkungan dan kesehatan. Serta diharapkan masyarakat membawa kantong belanja alternatif sendiri saat berbelanja dalam jenis apapun.

\section{DAFTAR PUSTAKA}

Abhiseka, I. G. D., \& Suharta, N. (2019). Implementasi Peraturan Walikota Denpasar Nomor 36 Tahun 2018 Tentang Pengurangan Kantong Plastik. Jurnal Kertha Negara, 7(6), 1-12.

Adhi, G. P. O. B., Rideng, I. W., \& Widiati, I. A. P. (2021). Pelaksanaan Peraturan Gubernur Bali Nomor 97 Tahun 2018 Tentang Pemakaian Kantong Plastik Sekali Pakai di Kota Denpasar. Jurnal Interpretasi Hukum, 2(2), 346-352.

Akib, M. (2014). Hukum Lingkungan, Perspektif Global dan Nasional. Raja Grafindo Persada, Jakarta.

Arifin, M. Z. (2017). Dampak Sampah Plastik Bagi Ekosistem Laut. Buletin Matric, 14(1), 44-48.

Asshidiqie, J. (2005). Konstitusi dan Konstitualisme Indonesia. Sinar Grafika, Jakarta.

Blolo, Y. K. (2021). Implementasi kebijakan pengurangan penggunaan kantong plastik di Kota Denpasar. SOROT: Jurnal Ilmu-Ilmu Sosial, 16(1), 13-24.

Helmi. (2012). Hukum Perizinan Lingkungan Hidup. Sinar Grafika, Jakarta.

Karuniati, N. N., \& Muhammad, N. (2021). Implementasi Peraturan Walikota Denpasar Nomor 36 Tahun 2018 Tentang Pengurangan Penggunaan Kantong Plastik. Jurnal Ilmu Sosial Dan Ilmu Politik, 35(1), 1-8.

Kubontubuh, E. D. (2019). Bali Bebas Sampah Plastik (Menuju Clean and Green Island). Jurnal Bali Membangun Bali, 2(1), 41-46.

Manik, K. E. S. (2009). Pengelolaan Lingkungan Hidup. Djambatan, Jakarta. 